\title{
EFEKTIVITAS AIR REBUSAN JAHE MERAH TERHADAP INTENSITAS NYERI HAID
}

\author{
Eline Charla Sabatina Bingan ${ }^{\bowtie}$ \\ Jurusan Kebidanan Poltekkes Kemenkes Palangka Raya
}

\section{ARTICLE INFO \\ Article history}

Submitted : 2019-09-11

Revised : 2021-06-23

Accepted : 2021-07-28

Keywords:
Menstrual pain
Red ginger
Teenage girl

\section{Kata Kunci:}

Nyeri haid

Jahe merah

Remaja putri

\begin{abstract}
Menstrual pain is a natural thing that is experienced by women when they are menstruating, but menstrual pain has normal limits, if the menstrual pain is felt excessive then it must be overcome. The purpose of this study is to find out this research is to determine the effectiveness of red ginger boiled water to reduce the intensity of menstrual pain in female students at Poltekkes Kemenkes Palangka Raya. This research method uses a Pre-experimental research type with a One Group Control Pretest-Posttest Design study. The population of this research is female students at Poltekkes Palangka Raya and the sample size is 73 respondents with the sampling technique used is purposive sampling. The statistical test used in this study was the Wilcoxon test. The results of the statistical test showed the value of $Z=-7.047$, which means that giving red ginger drink 7.047 times can help reduce the intensity of pain during menstruation. Statistical test results obtained a $\mathrm{p}$ value of $0.001 \quad(\mathrm{p}<0.05)$ meaning that there is an effect of red ginger boiled water on decreasing the intensity of menstrual pain. Red ginger boiled water can help reduce the intensity of menstrual pain.

Nyeri haid adalah suatu hal yang wajar di alami pada wanita saat sedang menstruari, tetapi nyeri haid tersebut memiliki batas kenormalan, jika nyeri haid yang dirasakan berlebihan maka harus diatasi . Tujuan dari penelitian ini yaitu untuk mengetahui penelitian ini untuk mengetahui efektivitas air rebusan jahe merah untuk mengurangi intensitas nyeri haid pada mahasiswi di Poltekkes Kemenkes Palangka Raya. Metode penelitian ini menggunakan Jenis penelitian Pre experimental dengan studi One Group Control Pretest-Posttest Design. Populasi penelitian ini adalah Mahasiswi di Poltekkes Palangka Raya dan besar sampel sebanyak 73 responden dengan tehnik sampling yang digunakan adalah purposive sampling. Uji statistik yang digunakan pada penelitian ini adalah uji Wilcoxon. Hasil Uji statistik menunjukkan nilai $\mathrm{Z}=-7,047$ yang artinya pemberian minuman ramuan jahe merah 7,047 kali dapat membantu mengurangi intensitas nyeri pada saat haid. Hasil uji statistik didapatkan nilai $p$ value sebesar 0,001 $(\mathrm{p}<0,05)$ artinya ada pengaruh air rebusan jahe merah terhadap penurunan intensitas ny eri haid. Air rebusan jahe merah dapat membantu mengurangi intensitas nyeri haid.
\end{abstract}

\footnotetext{
$\triangle$ Corresponding Author:
}

Eline Charla Sabatina Bingan

Jurusan Kebidanan Poltekkes Kemenkes Palangka Raya

Telp. 085249210188

Email: elinecarlabingan@gmail.com

\section{PENDAHULUAN}

Dismenore biasanya terjadi sebelum atau saat sedang menstruasi, dismenore paling banyak terjadi pada masa remaja atau masa produktif. Data WHO (World Health Organization) tahun 2014 menunjukkan di beberapa negara seperti di Swedia sekitar $72 \%$ perempuan mengalami dismenore. Di Amerika Serikat $90 \%$ wanita mengalami dismenore (Jurnal Occupation And Environmental Medicine, 2008).

Berdasarkan data dari Profil Kesehatan Kalimantan Tengah tahun 2015 ditemukan masalah kesehatan reproduksi sebesar 63,64\% wanita yang mengalami dismenore. Pada survei awal yang peneliti lakukan dengan metode wawancara terhadap 10 mahasiswi Sarjana Terapan Kebidanan Angkatan IV Poltekkes Palangka Raya yaitu dari 10 responden di dapatkan 7 responden mengalami nyeri haid disertai kram perut,diare,mual, konsentrasi yang menurun.

Cara untuk mengurangi dismenore bisa denga metode farmakologis yaitu dengan obat anti nyeri , nonfarmakologis yaitu herbal seperti jamu,pengaturan posisi, teknik relaksasi, manajemen sentuhan, manajemen lingkungan, 
distraksi, imajinasi, kompres dan pemberian minuman herbal yang direbus.

Tanaman jahe merah atau Zingiber Officinale Roxb. Var. Rubra adalah jenis tanaman yang termasuk tanaman herbal yang memilik batang semu berwarna hijau dengan tinggi kira-kira $40-50 \mathrm{~cm}$ berbentuk seperti rimpang yang mengandung $2-3 \%$ minyak atsiri terdiri dari zingiberin, kemferia, limonene, borneol, sineol, zingiberal, linalool, geraniol, kavikol, zingiberol, gingerol, dan shogaol (Winarti, 2008 ; Rahnama et al., 2012).

Dalam penelitian Arifiana (2014) didapatkan hasil dari 16 responden terdapat lebih dari $50 \%$ mengalami nyeri sedang yaitu sebanyak 11 responden $(68,8 \%)$, dan nyeri berat 5 responden $(31,2 \%)$. Setelah diberikan terapi minuman jahe terdapat lebih dari $50 \%$ mengalami nyeri ringan yaitu sebanyak 10 responden $(62,5 \%)$, nyeri sedang \% responden $(31,3 \%)$ dan tidak mengalami nyeri 1 responden $(6,3 \%)$. Berdasarkan latar belakang tersebut peneliti tertarik untuk meneliti mengenai efektivitas air rebusan jahe merah terhadap intensitas nyeri haid pada mahasiswi di Politeknik Kesehatan Palangka Raya.

\section{METODE PENELITIAN}

\section{Jenis Penelitian}

Jenis penelitian ini yaitu Pre experimental dengan studi One Group Control Pretestposttest Design.

\section{Lokasi dan Waktu Penelitian}

Penelitian ini dilakukan pada bulan Januari April 2019 bertempat di Poltekkes Kemenkes Palangka Raya.

\section{Populasi dan Sampel}

Populasi penelitian ini adalah seluruh mahasiswi di Poltekkes Kemenkes Palangka Raya dengan jumlah sampel sebanyak 73 responden yang memenuhi kriteria insklusi penelitian dengan teknik sampling yaitu purposive sampling.

\section{Pengumpulan Data}

Alat pengumpulan data pada penelitian ini adalah lembar kuesioner, skala nyeri NRS dan skala distress. Hasil pengukuran dismenore pada mahasiswi kebidanan pre dan post intervensi disajikan dalam bentuk kuesioner dengan skala nyeri NRS interval.
Untuk membuat air rebusan jahe merah peneliti menggunakan jahe merah 10 gram, gula merah 10 gram dan air 400 ml. Cara pembuatannya yaitu jahe merah dikupas terlebih dahulu, dicuci bersih dengan air mengalir, jahe merah yang sudah diris lalu direbus dengan $400 \mathrm{ml}$ air, rebus hingga airnya tersisa $200 \mathrm{ml}$. Dinginkan air rebusan jahe merah tersebut dan jika sudah dingin masukkan ke dalam botol. Air rebusan jahe merah tersebut dapat dikonsumsi oleh responden 1 kali sehari selama menstruasi. Uji statistik yang digunakan pada penelitian ini adalah uji Wilcoxon. Penelitian telah diuji etik dan disetujui oleh Komisi Etik Penelitian Kesehatan Poltekkes Kemenkes Palangka Raya dengan Nomor: 086/IV/KE.PE/2018 pada tanggal 11 November 2018.

\section{HASIL PENELITIAN}

Berdasarkan tabel 1 , usia yang paling terbanyak pada usia $>20$ tahun yaitu 66 mahasiswi $(91 \%)$, siklus haid terbanyak pada siklus haid 21 - 35 hari yaitu 59 mahasiswi $(80,8 \%)$ dan lama haid terbanyak pada lama haid >3 hari yaitu 70 mahasiswi (96\%).

Tabel 1. Distribusi Fre kuensi

\begin{tabular}{lcc}
\hline \multicolumn{1}{c}{ Variabel } & $\mathbf{N}$ & $\mathbf{\%}$ \\
\hline Usia & & \\
$<20$ tahun & 7 & 9 \\
> 20 tahun & 66 & 91 \\
\hline Siklus Haid & & \\
< 21 hari & 10 & 13,7 \\
21 - 35 hari & 59 & 80,8 \\
$>$ 35 hari & 4 & 5,5 \\
\hline Lama Haid & & \\
3 hari & 3 & 4 \\
< 3 hari & 0 & 0 \\
$>3$ hari & 70 & 96 \\
\hline
\end{tabular}

Berdasarkan tabel 2, nyeri haid yang terbanyak sebelum diberikan air rebusan jahe merah yaitu nyeri haid sedang dengan 38 mahasiswi $(52,1 \%)$ dan sesudah diberikan air rebusan jahe merah nyeri haid terbanyak yaitu nyeri haid ringan dengan 59 mahasiswi $(80,8 \%)$.

Berdasarkan tabel 3, menunjukkan nilai $\mathrm{Z}=-7,047$ yang artinya pemberian air rebusan jahe merah 7,047 kali dapat membantu mengurangi intensitas nyeri pada saat haid. 
Tabel 2. Analisis Bivariat

\begin{tabular}{lcccc}
\hline Nyeri Haid & \multicolumn{2}{c}{ Sebelum } & \multicolumn{2}{c}{ Sesudah } \\
\cline { 2 - 5 } & $\mathbf{N}$ & $\mathbf{\%}$ & $\mathbf{N}$ & $\mathbf{\%}$ \\
\hline Nyeri ringan & 18 & 24,7 & 59 & 80,8 \\
Nyeri sedang & 38 & 52,1 & 13 & 17,8 \\
Nyeri berat & 17 & 23,3 & 1 & 1,4 \\
\hline
\end{tabular}

Tabel 3. Perbedaan Intensitas Nye ri Haid

\begin{tabular}{cc}
\hline & Posttest-Pretest \\
\hline $\mathrm{Z}$ & $-7,047$ \\
Asymp. Sig. & 0,001 \\
(2-tailed) & \\
\hline
\end{tabular}

\section{PEMBAHASAN}

Nyeri saat menstruasi atau sering disebut dengan dismenorrhea adalah hal yang wajar jika tingkat dismenorrheanya tidak berlebihan respon tubuh terhadap nyeri, didukung dengan kondisi psikis pada setiap individu saat menstruasi berlangsung (Winaris, 2016).

Siklus haid adalah jarak antara tanggal mulainya menstruasi yang lalu dan mulainya menstruasi berikutnya. Panjang siklus haid yang normal dianggap sebagai siklus menstruasi yang klasik ialah 28 hari ditambah atau dikurangi $2-3$ hari. Siklus haid adalah rentang hari sejak pertama haid hingga hari pertama haid berikutnya. Selama beberapa tahun pertama haid terasa nyeri, hingga membuat wanita merasakan sakit. Sedangkan siklus menstruasi tidak teratur diartikan sebagai siklus haid yang lebih pendek dari 21 hari atau lebih panjang dari 35 hari. Siklus juga dapat dikatakan tidak teratur jika jarak antar siklus bervariasi.

Lamanya menstruasi disebabkan oleh faktor psikologis yaitu berkaitan dengan tingkat emosional remaja putri yang labil ketika baru menstruas dan faktor fisiologis mengarah pada kontraksi otot uterus yang bekerja berlebihan terhadap hormon ini sehingga akibatnya endometrium dalam fase sekresi memproduksi hormon prostaglandin yang terbentuk dari asam lemak tidak jenuh yang disintesis oleh seluruh sel yang ada di dalam tubuh. Jika lamanya menstruasi terjadi lama, maka hormon prostaglandin yang dikeluarkan semakin banyak sehingga, akan timbul rasa nyeri yang berlebihan saat menstruasi (Smeltzer \& Bare, 2016).

Saat wanita sedang menstruasi yang disertai dengan rasa nyeri, maka rasa strees pun akan muncul karena terjadinya pelepasan hormon corticotropic relesing hormone atau $\mathrm{CRH}$ yang berasal dari hipotalamus yang mengakibatkan terhambatnya sekresi GnRh di nucleus arkuata.

Hasil penelitian pada penelitian ini yaitu pemberian air rebusan jahe merah 7,047 kali dapat membantu mengurangi intensitas nyeri pada saat haid. Rasa nyeri akibat adanya hormon prostaglandin yang membuat otot uterus berkontraksi. Nyeri haid dapat diatasi dengan terapi non farmakologi seperti ramuan jahe merah yang berfungsi dapat mengurangi nyeri haid. Karena jahe merah termasuk tanaman herbal, memiliki rimpang berwarna merah dan lebih kecil mengandung $2-3 \%$ minyak atsiri. Hal ini menunjukkan adanya hubungan penurunan nyeri haid dengan penggunaan jahe merah yang mana kandungan di dalam jahe merah sangat berguna sebagai terapi nonfarmakologi pada nyeri haid atau dismenore.

Hasil penelitian Utari (2015) menyatakan bahwa ramuan jahe yang diberikan pada remaja yang mengalami haid dapat membantu mengurangi nyeri haid. Penelitian Juliana (2014) menyatakan bahwa minuman rempah jahe asam dapat membantu mengurangi nyeri haid pada mahasiswi keperawatan.

\section{KESIMPULAN DAN SARAN}

Air rebusan jahe merah dapat membantu mengurangi nyeri haid pada mahasiswi di Poltekkes Kemenkes Palangka Raya. Bagi tenaga kesehatan diharapkan dapat mempromosikan atau memberikan edukasi cara untuk mengurangi nyeri haid yaitu dengan cara mengkonsumsi ramuan jahe merah yang bersifat ekonomis dan mudah didapatkan.

\section{DAFTAR PUSTAKA}

Alam, S., Hakimi, H., Sembiring, T., Deliana, M., \& Lubis, S. M. (2011). School performance in pubertal adolescents with dysmenorrhea. Paediatrica Indonesiana, 51(4), 213-6. [Diakses pada tanggal 10 desember 2018].

Batubara, J. R. (2016). Adolescent development (perkembangan remaja). Sari pediatri, 12(1), 21-9 [ Diakses pada 
tanggal 14 desember 2018].

Calis, Karim Anton. (2011). Dysmenorrhea [Online]. Dari: http://emedicine. medscape.com/article/253812-overview.

[Diakses pada tanggal 14 desember 2012].

Deswita. (2006). Psikologi Perkembangan. Bandung: Remaja Rosdakarya.

Dinkes Kalimantan Tengah. (2015). Profil Kesehatan Kalimantan Tengah [Online], dari: http://depkes.go.id. [Diakses pada tanggal 13desember 2012].

Edmundson, Laurel D. (2006). Dysmenorrhea Overview E-medicine Emergency Medicine [Online], dari: http//emedicine. medscape.com/article/ 79567-overview/. [Diakses pada tanggal 11 desember 2018].

Faizah, Jasin (Alih bahasa Burn,A.A, et al) (2000), Pemberdayaan Wanita Dalam Bidang Kesehatan. Yogyakarta: Yayasan Essentia Medica.

Harlow, S. D. \& Park, M. (1996). BJOG:An International Journal of Obstetrics \& Gynaecology [Online] Volume 103 No 11 (1134-1142), dari: http//obgyn. onlinelibrary.wiley.com. [Diakses pada tanggal 17 desember 2018].

Hidayat A. A. (2014). Metode Penelitian Kebidanan dan Teknik Analisis Kasus. Jakarta: Salemba Medika.

IMCW. (2007). Dismenore (Nyeri Haid) [Online], dari: http://www. MyDinariraq.com. [Diakses pada tanggal 15 desember 2018].

Kinanti, WA. (2013). Pengaruh Minuman Rempah Jahe Asam dalam Mengurangi Nyeri Dismenore Primer pada Mahasiswi Keperawatan Angkatan 2010-2012 Universitas Jenderal Soedirman
Purwokerto: Universitas Jenderal Soedirman.

Machfoedz, Mahmud. (2010). Komunikasi Pemasaran Modern. Cetakan Pertama Cakra Ilmu: Yogyakarta.

Manuaba. IB. (2001). Penuntun Kepaniteraan Klinik Obstetri dan Ginekologi. Jakarta : EGC.

Moersitawati. (2008). Tumbuh Kembang Anak dan Remaja. IDAI, Sagung Seto: Jakarta.

Ningsih, R. (2011). Efektifitas Pereda Intensitas Nyeri pada Remaja dengan Dismenore di SMAN Kecamatan Curup. Thesis. Fakultas Ilmu Keperawatan, Universitas Indonesia: Depok.

Nursalam. 2013. Konsep Penerapan Metode Penelitian Ilmu Keperawatan. Jakarta: Salemba Medika.

Purwanti S. (2013). Jurnal Kebidanan. Anal Perbedaan Ter Dismenore dengan Metod Effleurage, Kneading dan Yoga dalam mengatasi Dismenore [Online].

Tobergte, D.R., \& Curtis, S. (2013) Pengaruh Nyeri Haid Terhadap Aktifitas Seharihari di SMPN 2 Ponorogo Journal of Chemical Information and Modeling [Online], Volume 53 No 9 (1698-1699), dari: http://doi.org/ 10.1017/ CBO9781107415324.00. [Diakses pada tanggal 15 desember 2018].

Wiknjosastro, H. (2005). Ilmu Kandungan. Yayasan Bina Pustaka Sarwono Prawirohardjo: Jakarta.

Winaris, Imam Wahyu. (2010). Menstruasi. Jakarta : Tunas Publishing.

Winarti, C. \& Hernani. (2008). Kandungan Bahan Aktif Jahe dan Pemanfaatannya Dalam Bidang Kesehatan StatusTeknologi Hasil Penelitian Jahe. Surabaya: Trubus Agrisarana. 